GRZEGORZ MiceK

Jagiellonian University, Poland

Pauline Gleadle

Norwich Business School, University of East Anglia, Norwich, United Kingdom

PIOTR DAWIDKO

Jagiellonian University, Poland

\title{
The Role of Institutional Context in the Development of the SME Biotech Sector in Poland
}

\begin{abstract}
Whilst Poland is argued to represent one of the largest and most entrepreneurial economies in CE with huge potential for development of the SME biotech industry, this sector remains relatively underdeveloped. In this paper, we explore reasons for this apparent anomaly, focusing on the interrelationships between institutional context and entrepreneurial behaviour. We adopt Smallbone and Welter's (2009a, b) typology (Welter, Smallbone, 2011) of entrepreneurial behaviour in constructing a case study of the biotech SME industry in Poland, concluding that the sector faces particular institutional challenges which entrepreneurs react to in a variety of ways. We conclude that Poland presents serious obstacles to a knowledge-intensive sector such as biotech.
\end{abstract}

Key words: Biotech; entrepreneurial behaviour; institutional challenges; Poland

\section{INTRODUCTION}

Biotechnology generally is recognised as a sector in which SME entrepreneurs play a major role (e.g. Haslam et al., 2011) and at the same time Poland as a country represents one of the largest post-socialist economies in Central Europe $(\mathrm{CE})^{1}$ and one of the most entrepreneurial (Estrin, Mickiewicz, 2010). However, in Poland, despite certain favourable conditions which we will discuss later, we see an underdevelopment of the biotech industry, so in this paper we explore reasons behind this apparent anomaly. Specifically, we focus on the interrelationships between institutional context and entrepreneurial behaviour of SME biotech entrepreneurs in Poland. Hence, in contrast to Welter and Smallbone (2011) and Smallbone and Welter (2010), we focus not on manufacturing or trade industries, but on a knowledge-intensive sector, represented by biotechnology. We argue that existing typologies of entrepre-

1 Post-socialist Central European countries refer to, for instance, Poland and Hungary which were not formally a part of the Soviet Union. 
neurial behaviour (which we refer to in the rest of this paper as Welter and Smallbone, 2011) do not fully fit the biotechnology industry and, moreover, that typologies of business models in biotech (Clarysse et al., 2003) are outdated and do not take into account the institutional frameworks of countries in transition. We follow Peng (2000) cited in Welter and Smallbone (2011: 116) in arguing that not all companies react to changing institutional context in the same way, so presenting different responses to institutional pressures and hence exhibiting different types of entrepreneurial behaviour. However, Welter and Smallbone's (2011: 108) study covered examples of companies from mainly former Soviet republics rather than from CE post-socialist countries. To summarise, we contribute to the literature by exploring entrepreneurial behaviour in a knowledge-intensive sector in a CE post-socialist country. This is particularly pertinent given Mroczkowski and Elms's (2009) and Suurna's (2011) comments that little is known about biotech industry development in emerging knowledge-based economies of $\mathrm{CE}$ and that more research is needed on comparative biotechnology development in these countries. However, importantly the biotech industry in Poland is not well-developed in relation to its potential, so this paper explores the reasons why. We argue that some of the reasons for this are to be found in Poland's institutional obstacles. Whilst Welter and Smallbone (2011: 108) see Poland and other accession countries as less challenging environments for entrepreneurs than some former Soviet republics, we argue that Poland poses particular institutional problems for the biotech sector as an example of a knowledge-intensive industry. In so doing, the paper adopts the following structure.

Firstly, we discuss institutional perspectives and their relationship to theories of entrepreneurial behaviour. After setting out some key aspects of the biotech industry in Poland, we discuss our methodology. Institutional challenges facing the Polish biotech industry then provide the background against which we discuss the types of entrepreneurial behaviour in the sector. We distinguish three over-arching types of entrepreneurial behaviour with respect to the following categories: regulation, business portfolios and funding. Underlying the latter, we argue there is a strong desire for independence on the part of the entrepreneurs. We conclude that the institutional challenges facing Polish biotech industry constitute constraints on entrepreneurial behaviour. We turn then to the topic of institutionalism.

\section{INSTITUTIONAL FRAMEWORK}

North (1994) developed an institutional perspective which we argue to be a powerful analytical framework to understand economic change. Consequently, we adopt this framework to explore the arguably challenging environment of Poland, a country in transition (Welter, Smallbone, 2011). North $(1990,1994)$ frames institutionalism in terms of a combination of formal institutions (including at the legal and organisational levels) and informal codes of conduct, norms, beliefs and values. Formal rules and institutions that may change overnight pose a substantial challenge to entrepreneurs, so influencing their behaviour (Welter, Smallbone, 2011). For instance, legal frameworks (e.g. detailed regulations governing the 
calculation of value added tax or eligible costs in EU projects) shape funding systems and consequently also the growth of industry. By way of contrast, stable and predictable regulatory frameworks through reducing transaction costs, have a direct influence on entrepreneurship behaviour. Hence, deficient legal systems (such as unclear intellectual property rights or the lack of specialist commercial and property lawyers), constrain the functioning of formal organisations and so hamper the growth of industry.

We argue that excessive changes (both of a positive and of a negative nature) complicate institutional systems, leading to a more unpredictable life for entrepreneurs. Our analysis adopts an institutional framework in an heuristic fashion. In so doing, we pay close attention to the roles of institutions, history and political economies in explaining the challenges facing the Polish biotechnology. We believe that institutions provide both opportunities as well as constraints in economic development, on an organisational scale and at a more individual level, on entrepreneurial behaviour.

Niosi (2011: 1798) distinguishes four types of institutions important to the biotechnology industry: organisations (firms, universities, government departments and research institutes, venture capital partnerships), routines (repetitive patterns of actions within organisations that may cause enormous inertia), norms or customs (patterns of social actions based on common attitudes, expectations, beliefs, values etc.) and laws or policies imposed by regional, national or EU legislation. Bartholomew (1997, cited by Niosi, 2011: 1803) distinguishes eight elements in the institutional structure of biotechnology:

- the level and patterns of national funding of basic research;

- the linkages with foreign research institutions;

- the national tradition of scientific education;

- the degree of commercial orientation of research institutions;

- labour mobility between university and industry;

- the venture capital market;

- the role of government in technology diffusion;

- technological accumulation in related sectors.

Whilst the focus of the current study is upon entrepreneurial behaviour in the face of particular institutional challenges in relation to Poland as an economy in transition, we will return to this issue of the sectoral requirements of biotech in our conclusions.

Of particular relevance to countries such as Poland, an observed unwillingness to act as an entrepreneur in risk-intensive businesses and transition economies may have deep roots in a nation's communist heritage. In this connection, Estrin and Mickiewicz (2010) point at the relatively slow pace of development of informal institutions and their effect on social attitudes, notably the low levels of generalised trust. "Thus, trust is an essential prerequisite for entrepreneurship but the transition countries share a negative heritage of a system based on authoritarian hierarchical organisation and detailed surveillance of all citizens" (Estrin, Mickiewicz, 2010: 11).

Estrin and Mickiewicz (2010: 10) mention the lower levels of autonomy and mastery among entrepreneurs that "remain(ed) much weaker in post-communist societies than in comparator West European societies in the mid-1990s". Arguably, this may be a legacy 
partly of the rigidly hierarchical relationships common between citizens and officials under communism.

Estrin and Mickiewicz (2010: 6-7) list institutional legacies of communism that are not conducive to entrepreneurship: “(...) the quality of commercial code, the strength of legal enforcement, administrative barriers to entry and to business activities, the prevalence of extra-legal payments and a lack of market-supporting institutions".

According to Sztompka (1996), these communist legacies resulted in attitudes of excessive dependence and conformity. Welter (2011) argues that context is important for understanding when, how, and why entrepreneurship happens (or does not happen) and who acts in an entrepreneurial fashion. In our paper we look at the business context and the somewhat neglected institutional context (Welter, 2011). We argue that the institutional context in Poland remains influenced by its communist legacy.

\section{ENTREPRENEURIAL BEHAVIOUR}

The majority of entrepreneurship theories focus on the micro-level foundations of entrepreneurial behaviour, "taking the external environment (including institutions) as given" (Smallbone et al., 2010: 657). Based on empirical research (e.g. Peng, 2003; Manolova et al., 2008) we follow Smallbone and Welter (2006) and Smallbone et al. (2010) in arguing that such an approach is inappropriate to transition economies, where external influences on entrepreneurial behaviour are both enormous and unstable.

We understand entrepreneurial behaviour as being a response to a particular set of external (institutional) environmental conditions. However, we adopt a wide definition of entrepreneurial behaviour that encompasses entrepreneurs' reactions to a volatile or hostile external environment, both while setting up or running a business.

The most recent typology of entrepreneurial behaviour in a transition context has been provided by Welter and Smallbone (2011). Based on previous studies conducted mainly in former Soviet Union republics (Smallbone, Welter, 2009a, 2009b) six types of entrepreneurial responses to institutional framework have been identified. The first type of managerial behaviour is called 'prospecting' (1) (Peng, 2000: 178) and is used to characterise firms "with a changing market, a focus on innovation and change and a flexible organisational structure". Such a strategy of frequent change of products/services cannot be always treated positively, but may in some cases constitute a necessary element of survival (Welter, Smallbone, 2011). An 'evasion' strategy (2) may be the only way to survive for the company, especially in difficult environments where taxes are high and bribes have to be proffered. 'Financial bootstrapping' type (3) refers to a behaviour that is followed under conditions of scarcity of capital from formal sources. In such cases, serial entrepreneurship may be necessary just in order to accumulate the financial resources to start a business. The fourth type named 'diversification and portfolio entrepreneurship' (4) may apply to companies that offer additional non-core services or products which may contribute to a firm's revenues in conditions of volatile, 
unpredictable or scarce demand. The reason behind such diversification quoted by Welter and Smallbone (2011: 111) can include making "business success less visible to officials and those who may seek to make money from «offering protection»". The next type (5) of entrepreneurial response to external influences is based on developing networks of personal contacts (with friends and acquaintances) for business purposes. Finally, type (6), adaptation behaviour, is based on the necessity of dealing with complicated administrative regulations and laws, and to adapt to these even if doing so may be cumbersome and expensive. Whilst we endorse Welter and Smallbone's (2011) typology, we would suggest that this could be re-grouped around three core dimensions of entrepreneurial responses towards: regulations, business portfolios and funding (Tab. 1).

Tab. 1. Dimensions of entrepreneurial behaviour

\begin{tabular}{|l|l|}
\hline \multicolumn{1}{|c|}{$\begin{array}{c}\text { Dimensions of } \\
\text { entrepreneurial behaviour }\end{array}$} & \multicolumn{1}{c|}{ Type of entrepreneurial behaviour (Welter, Smallbone, 2011) } \\
\hline Regulations & $\begin{array}{l}\text { (Tax) evasion (2) } \\
\text { Networking (5) } \\
\text { Adaptation strategy (6) }\end{array}$ \\
\hline Business portfolio & $\begin{array}{l}\text { Prospecting behaviour (1) } \\
\text { Diversification and portfolio entrepreneurship (4) }\end{array}$ \\
\hline Funding & Financial bootstrapping (3) \\
\hline
\end{tabular}

Source: own elaboration based on Welter, Smallbone, 2011

We turn next to an overview of the biotech industry in Poland. In this paper, we are focusing on medical ('red') biotechnology industry, the largest branch of the biotech sector in Poland. Over half of the Polish biotech companies surveyed by the National Statistical Office are involved in medical biotechnology (Nauka i Technika, 2011). We focus on dedicated biotechnology firms (DBFs), whose predominant activity, according to the OECD, involves the application of biotechnology techniques to produce goods or services and/or to perform biotechnology R\&D (van Beuzekom, Arundel, 2009).

\section{Background to the Biotech Industry IN Poland}

Poland is argued to be amongst one of the most entrepreneurial countries in CE (Estrin, Mickiewicz, 2010). However, whilst the number of firms generally increased sharply in what has been described in Poland as "an explosion of entrepreneurship" (Piasecki, Rogut, 1993, cited by Smallbone, Welter, 2006) after the liberalising reforms of 1988, there has been limited development of the biotech industry compared with some other CE countries such as Hungary (Mroczkowski, Elms, 2009). The number of firms meeting the narrow definition of dedicated biotech firms is disputed. Mroczkowski and Elms (2009) give this number as encompassing 20 firms with 1172 employees at that time, of whom 232 were directly involved 
in $R \& D$, although according to our own calculations the number of dedicated biotech companies in Poland in 2010 was 49 with the employment reaching 3000 in total.

We argue that the Polish biotechnology industry is different from its Western European counterparts in important respects. There is both limited Big Pharma engagement and also little venture capital investment. With respect to the latter, in late 2011 there were only two VC funds which specialized in life sciences, JCI Ventures and MCI BioVentures, which together own 11 portfolio companies including three DBFs. There are two foreign companies operating in the biotech industry in Poland. Over 50\% of Polish DBFs are academic spin-offs.

Since Poland's accession to the EU in 2004, European funding has played an important role in the country's overall development. The Innovative Economy Programme ${ }^{2}$, funded mainly by the European Regional Development Fund and managed by the Polish Agency for Enterprise Development (known as PARP in Polish ${ }^{3}$ ) is the main EU financial support mechanism for high-technology firms, including the biotech sector. Between 2007 and 2010 Polish biotech firms signed public financing agreements worth PLN 139 million. This constitutes, however, only $1 \%$ of the total value of agreements signed on behalf of the Programme, so that EU funds used to develop the Polish biotech industry have been minimal historically, although this source of funding is becoming much more significant particularly for the quoted biotech SMEs.

Advantages enjoyed by the Polish biotech industry include importantly that the country benefits from a large and relatively well-developed network of medical schools and hospitals. Consequently, Poland has a good track record as a competitive international destination for pre-clinical and clinical trials, with academic pharmacology and life sciences being of a high standard (Mroczkowski, Elms, 2009). Further positive features of the industry according to the Europabio and Venture Valuation report (2009) include that the industry has an adequate science infrastructure. As examples of the latter, life science cluster initiatives have been established in Kraków, Wrocław and Gdańsk in addition to 30 science and technology parks in the country, and there has been a mushrooming of technology transfer offices at universities and R\&D institutes. Accordingly, we argue that the potential for development of the industry is strong, but that actual development to date remains weak.

It is this background and the embedded three publicly quoted SME biotech firms by the end of 2010 that we explore using the following methodology.

2 The programme constitutes the largest source of funding for entrepreneurs who want to implement innovative R\&D projects and use information and communication technologies. For the period 2007-2013 funding exceeds EUR 10 billion (85\% of this amount coming from the European Regional Development Fund, with the rest originating from the state budget).

3 The Polish Agency for Enterprise Development (known as PARP in Polish) provides support to small and medium entrepreneurs. PARP aims to facilitate such matters as the use of innovative solutions by entrepreneurs, development of human resources, expansion in international markets and regional development, so improving the competitiveness of the Polish economy. In supporting entrepreneurs, PARP uses funds from both the state budget and the EU. For the period 2007-2013, PARP had responsibility for the implementation of measures under three Operational Programmes, including Innovative Economy (Welcome to the Polish Agency of Enterprise Development, 2012. Retrieved April 25, 2012, from http://en.parp.gov.pl/. 


\section{Methodology}

We follow Froud et al.'s (2006) narrative and numbers approach in constructing a case study of the biotech industry in Poland as a whole in distinction to their approach in which they analyse three individual multinational companies. Our narratives consist both of publicly available press interviews in Polish as well as our own interviews with six key actors in the Polish biotech industry as at the end of 2010: entrepreneurs, representatives of biotech companies and institutions that support biotech industry. The focus of these interviews was to understand both institutional challenges and entrepreneurial behaviour in the Polish biotech industry. Additionally, we referred to other publicly available narrative information in both Polish and English.

Numbers used in constructing our case study of Polish biotech included our own database of all DBFs, both public and private operating in the country, based on a variety of sources: the Hoppenstedt Bonnier database, companies' websites and press interviews. The database details the following: the firm's year of establishment, number of employees, founders, owners and modes of establishment. Possible establishment modes consisted of Foreign Direct Investment (FDI), academic spin-off, spin-off from another company or change of profile from a firm that was previously non-biotech in character.

Finally, in order to ground our overall case of the Polish biotech industry in more detailed empirical data, we focus on the three publicly quoted biotech SMEs as at the end of 2010. For this, we used publicly available information in both Polish and English. This included company annual reports and other periodical financial information (semi-annual, quarterly) and listing documents.

We use this multi-source methodology to situate the Polish biotech industry against the background of its institutional challenges.

\section{Institutional Challenges facing the Polish Biotech Industry}

\section{Poor linkages/cooperation between science and industry}

In $\mathrm{CE}$, research and science institutions are sometimes referred to as being like 'ivory towers' with limited contact with the business world (Mroczkowski, Elms, 2009). Similarly, Malo and Norus (2009) note that the modern biotech industry in Poland started mainly in industrial R\&D institutes set up by communist ministries and science-funding bodies based in Warsaw and that, however well-funded, they never attained the level of sophistication found in public research organisations in more mature economies. Moreover, Malo and Norus (2009) cite Moore (2004) who writes about the poor legacy of misguided investment in Poland where as little as $20 \%$ of the entire public R\&D budget was invested in life sciences. The situation has not changed significantly in recent years, since based on the general science budget for 2011, "natural sciences" R\&D, a much wider category than biotechnology alone, 
was due to received PLN 268 million (excluding EU co-funding), or about $22 \%$ of total R\&D expenditure. Hence, a history of poor linkages between science and industry constitutes a major institutional challenge to the Polish biotech industry. This viewpoint is expressed by Professor Jan Lubiński, CEO of Read-Gene, a small quoted Polish biotech, in an interview published on 27/05/2009 on the biotechnologia.com.pl website: "We also need to change the way of thinking. We need to recognise the commercialisation of research as being something commendable, not questionable or controversial".

This is despite the large number of trained people, according to one of our interviewees, a biotech consulting micro firm owner, who are not willing to start a business.

According to another of our interviewees, the project manager of one of the Polish venture capital funds: "There is a low willingness to spin-off in universities and a lack of entrepreneurial culture, as for researchers only publications count. Researchers have an aversion to business. They would rather have 2 or 3 academic jobs instead - and so they end up having no time for starting their own businesses" (interview no. 2, 08/11/2010).

These attitudinal problems are compounded by problems related to patenting.

\section{Patenting is expensive}

Under communism, it was institutions rather than individuals who applied for patents in Poland. It is perhaps this legacy which explains why patenting is both time-consuming and expensive. Witek (2008) comments that at that time, for instance, a foreign patent application and protection in $\mathrm{PCT}^{4}$ mode would cost 14,500-17,500 PLN, a sum 4.5-5.5 times the average monthly salary. To reinforce this point, a 10-year European Patent Office patent (covering 8 EU countries) would cost 57,000 EUR (238,140 PLN), or 62 times the average monthly salary.

Moreover, in connection with patenting, the Europabio and Venture Valuation Report (2009) cites the lack of clear regulation of intellectual property rights (IPR) as constituting a major problem facing the Polish biotech industry. Indeed, most universities continue to retain rights to all research conducted both before and after patenting.

\section{Lack of life science policies}

Mroczkowski and Elms (2009) describe Poland as following a more laissez-faire approach to the development of the biotech industry. This is in contrast for example to Hungary which has adopted a relatively well-funded national strategy of launching a biotech sector specialised in innovative drug discovery. Although the Polish government declared support for the sector in 2008 with its action plan for biotechnology, as of 2012 there is no clear government policy on biotech development. Previously established advisory bodies, such as the Interdisciplinary Bio-economy Development Team, have been disbanded and calls from the industry, requesting the creation of a national biotech development strategy following the more support-oriented Hungarian or Estonian models. Despite some regional and local

4 A PCT application is an international application to protect inventions in one of the states that signed the Patent Cooperation Treaty (PCT). 
policy support, this lack of policy on the national level is well summarised by one of the directors of life science clusters, who said: "It is impossible to conduct life sciences in isolation from the rest of the world... The important problem in Poland is the lack of biotech-oriented funding policy" (interview no. 1, 25/10/2010).

\section{Changing legal framework}

One of the institutional challenges facing entrepreneurs in Poland relates to the constant legal changes partly due to EU enlargement, which affect companies including biotech. These can be difficult to keep up with, something recognised in the operation from 2008 of

the "Friendly State" parliamentary commission. This has as its aim the reform of unfriendly, unclear, inconsistent regulations that adversely affect entrepreneurial life.

Given such institutional challenges, it is perhaps unsurprising that academics tend to create spin-off companies only rarely. There are some heritage reasons for this, as under communism running a business was almost impossible except in certain very special circumstances. To this can be added the continuing difficulties posed by university regulations which, according to Rogut and Cieślak (2009: 259), "are rigid and practically non-negotiable, (so that) it becomes obvious why so many things are dealt with outside universities" rather than between university employees and firms.

\section{Lack of sustainable funding}

Biotechnology requires large public investment (Niosi, 2011) but deficiencies in national policy constitute a major reason behind the Polish biotech industry's lack of sustainable funding. "It's difficult to find funding and maintain R\&D for a longer period of time" (interview no. 5, biotech consulting micro firm owner, 10/02/2010).

Large-scale government funding tends to go to support substantial manufacturing projects rather than to knowledge-intensive industries, one interviewee commenting: "The government should change the direction of its investment as there is under-funding of science... 30 million PLN for a T-shirt factory versus 2 million for R\&D!” (interview no. 4, substantial private biotech firm spokesperson, 25/08/2010).

Looking at these institutional challenges we argue that they pose serious obstacles to the development of high technology and knowledge-intensive sectors. Given these institutional challenges we explore the applicability of Welter and Smallbone's (2011) typology of entrepreneurial behaviour to the case of biotech in Poland.

\section{TyPes OF ENTREPRENEURIAL BEHAVIOUR IN THE POLISH BIOTECHNOLOGY INDUSTRY}

Smallbone and Welter (2009a, b) and Welter and Smallbone (2011: 110) distinguish six types of entrepreneurial behaviour that are "distinctive responses to the external environment in which entrepreneurs were operating". We argue that these responses, rather than being 
distinctive, overlap to some extent. For instance, the fifth type , «networking» and personal contact for business purposes' may easily overlap with other types. In summary, we argue that each entrepreneur exhibits a different combination of types of entrepreneurial behaviour. For instance, in Read-Gene there is an evidence of 'prospective' and 'diversification of portfolio' behaviour with some signs of 'financial bootstrapping' at the time of the beginning of its operations.

While addressing entrepreneurial behaviour exhibited within the Polish biotech sector, we focus mainly on the three quoted SMEs as of the end of 2010 (see Appendix for summary details of these firms): Read-Gene, Euroimplant and Mabion. We also review further evidence of entrepreneurial behaviour discussed by other private companies we interviewed plus publicly available narratives on BioInfoBank ${ }^{5}$.

Tab. 2. Typologies of entrepreneurial behavior

\begin{tabular}{|c|c|c|}
\hline $\begin{array}{l}\text { Types of entrepreneurial behaviour } \\
\text { observed within the dimensions by } \\
\text { current authors }\end{array}$ & $\begin{array}{c}\text { Our dimensions } \\
\text { of entrepreneurial } \\
\text { behaviour }\end{array}$ & $\begin{array}{c}\text { Types of entrepreneurial behaviour } \\
\text { (Welter, Smallbone, 2011) observed } \\
\text { within the dimensions }\end{array}$ \\
\hline $\mathrm{A}$ & $\mathrm{B}$ & $\mathrm{C}$ \\
\hline $\begin{array}{l}\text { Adaptation strategy (A) } \\
\text { Active cooperation (B) } \\
\text { Open confrontation (C) }\end{array}$ & Regulations & $\begin{array}{l}\text { (Tax) evasion (2) } \\
\text { Adaptation strategy (6) } \\
\text { Networking (5) }\end{array}$ \\
\hline $\begin{array}{l}\text { Prospecting behaviour (D) } \\
\text { Diversification and portfolio } \\
\text { entrepreneurship (E) }\end{array}$ & $\begin{array}{l}\text { Business } \\
\text { portfolio }\end{array}$ & $\begin{array}{l}\text { Prospecting behaviour (1) } \\
\text { Diversification and portfolio } \\
\text { entrepreneurship (4) }\end{array}$ \\
\hline $\begin{array}{l}\text { Independent behaviour (F) } \\
\text { Investors cum ntrepreneurs (F1) } \\
\text { Single-person micro-firm (F2) }\end{array}$ & Funding & Financial bootstrapping (3) \\
\hline
\end{tabular}

Source: own elaboration

As discussed earlier, we have identified three over-arching dimensions to Welter and Smallbone's (2011) typology of entrepreneurial behaviour as shown in Table 2 above: regulations, business portfolio and funding (column B, Tab. 2). Column C represents the original Welter and Smallbone typology grouped around the above-mentioned three dimensions. Column A represents individual behaviour types observed by the current authors in the biotech industry within our three dimensions in column B. The relationship between the original Welter and Smallbone (2011) typology, our related dimensions and types of entrepreneurial behaviour observed within these dimensions by us is shown in Fig. 1 below.

5 BioInfoBank Institute is a hybrid non-profit organisation which undertakes applied R\&D and which has also established a seed capital fund to create and support biotech initiatives. Additionally, the organisation has received over 10 grants conducted under EU Framework Programmes. The lengthy BioInfoBank case study is presented in what they call a 'fairy tale' narrative format on their website. We argue it constitutes an important and interesting case as it is claimed that PARP tried to engage in sabotage against some Polish biotech companies, including themselves. 


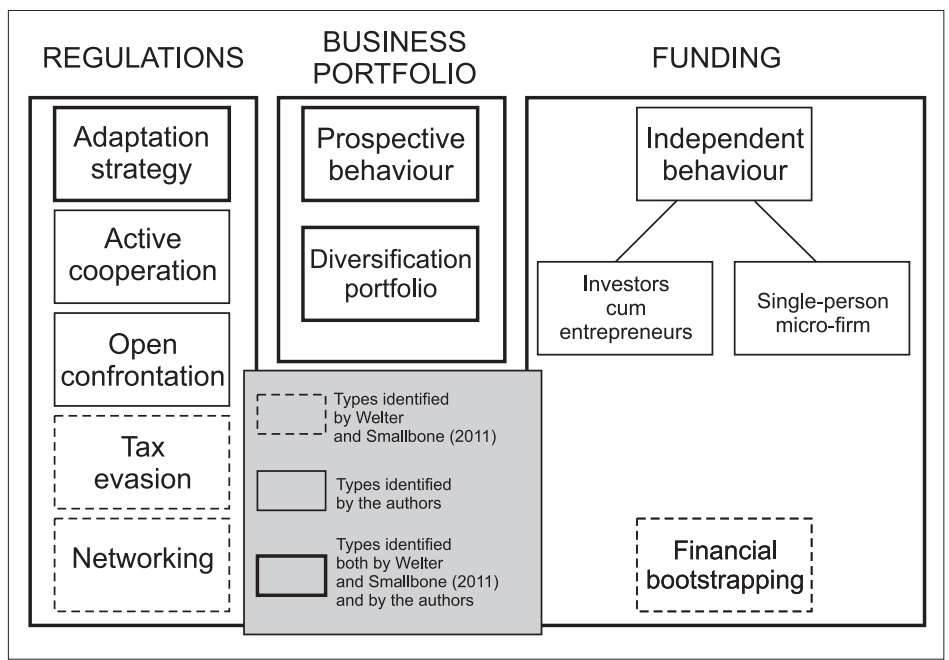

Fig. 1. Typologies of entrepreneurial behaviour and their inter-relationships

Source: own elaboration

\section{ENTREPRENEURIAL RESPONSES TOWARDS REGULATIONS}

We argue that a spectrum of companies' attitudes towards regulations may be distinguished. Firms' reactions to the challenging regulatory framework range from silent adaptation to hostile responses that are based on direct confrontations with regulatory organisations. On this spectrum at least four types of entrepreneurial behaviour of biotech companies can be identified. The simplest behaviour, although not necessarily the cheapest by any means, is to adapt to existing regulations and associated organisational framework (Type A). BioInfoBank Institute (Bajka ..., 2012) describes the case of a number of consultancies co-operating with PARP: "PARP was over-run by various consulting firms offering comprehensive support for grant application and handling. The same companies were engaged in organising conferences, training and inspection of projects, for which PARP was paying millions PLN. (...) The timeliness of payment transactions and the effectiveness of cooperation were supervised by PARP employees, who worked at the same time for consulting firms providing services to PARP and clients (author's note summarising lengthy discussion by BioInfoBank. The main point is that this situation led to a serious conflict of interests on the part of some PARP employees)".

We argue that despite these alleged problems in connection with PARP, some biotech firms are likely to have adopted an adaptation strategy (Type A of entrepreneurial behavior in Tab. 2 above) so as to increase their likelihood of obtaining grants.

Turning next to the biotech firms proper, some of the academic spin-offs find themselves needing to continue using such facilities as equipment and laboratories owned by 
the original host university. This approach of active cooperation (Type B of entrepreneurial behaviour in Tab. 2) with host universities is to be seen in the Read-Gene case and that of Biocentrum, a private biotech firm.

Due to the necessarily limited scope of the study, we were unable to uncover evidence of using personal contacts for business purposes. However, based on the biotech literature (e.g. Haslam et al., 2011), networking is crucial, but not necessarily in terms of exchange of favours and counter-favours and in dealing with authorities (Welter, Smallbone, 2011), but rather in co-operating as scientific colleagues.

Another type of entrepreneurial behaviour not identified by Welter and Smallbone (2011) concerns open confrontation with institutions and officials (Type $\mathrm{C}$ of entrepreneurial behaviour in Tab. 2), who "(...) do not understand the biotech industry" (to quote the spokesperson for a substantial private biotech firm (interview no. 4, 25/08/2010). We argue that such formal organisations as PARP may constitute indirect legacies of communism, given its rigidity and low understanding of the biotechnology industry. This applies even to organisations that are relatively newly established such as PARP, an arguably highly politicised agency in which managerial positions change with the advent of a new government. Because of such perceived deficiencies on the part of PARP, some organisations engage openly in a fierce struggle to obtain and retain funding from both agencies and ministries. Indeed, BioInfoBank decided to engage in an open confrontation with PARP. The founder of this highly successful organisation said in one publicly available interview: "We attempted to finance the company from the «Innovative Economy» Programme, but ended up going to court. (...)

I know of many firms that went bankrupt, because they were involved in the Innovative Economy Programme. (...) On the other hand, in highly subsidised industries, like biotechnology, you cannot compete without having a grant. If the owners are interested in such a high level of risk they could try to do so. (...) Unwillingness to cooperate on the part of PARP may lead to serious problems for companies" (Kuzdraliński, 2012).

Elsewhere, BioInfoBank criticise PARP and ministry officials for a lack of basic competence and consequently lack of basic understanding towards biotech.

With respect to the Welter and Smallbone (2011) typology, due to both the limitations of our data and sensitivity of the topic, we have not uncovered any evidence for 'tax evasion' behaviour. In any case, this behaviour is less likely to be applicable to quoted biotech companies which often do not pay taxes as they usually report losses during their early years.

Next, we posed the question as to how external factors influence entrepreneurial behaviour in terms of companies' business portfolios.

\section{ENTREPRENEURIAL BEHAVIOUR IN TERMS OF BUSINESS PORTFOLIOS}

Looking at Welter and Smallbone's (2011) typology we agree that both types of entrepreneurial response (change and diversification of the company's offering of products and services) are present in the biotech sector in Poland. 'Prospecting' behaviour (Type D) 
does exist in the Polish biotech sector, although the change of products and services is not as frequent as in trade or manufacturing, due to the nature of the industry which involves large amounts of capital spend and lengthy product pipelines. However, biotech firms themselves are active participants in actually influencing the market in terms of new types of services and solutions offered. As an example of this behavior, Euroimplant has started selling a cosmetics product, petals under the eyes, rather than concentrating purely on biotech proper. Some Polish biotech firms, therefore, tend to be highly flexible in their responses despite the rigidity constraints of the sector.

Another type of behaviour identified by Welter and Smallbone (2011) based on diversification of products (Type E) occurs in the early years of life of one of our cases, Euroimplant. The company reported relatively large revenues in 2007 that originated from renting out space and from consulting services rather than from its core biotech activities. This diversification of products or services presents a different case from one described by Welter and Smallbone (2011: 111), who write about entrepreneurs engaging in diversification in order to deal with problems of institutional deficiencies and corruption.

We have discussed earlier that the scarcity of sustainable funding in the Polish biotech industry poses a substantial institutional challenge. This then raises the question as to what types of behaviour in terms of funding strategies do Polish biotech firms follow?

\section{ENTREPRENEURIAL BEHAVIOUR IN TERMS OF FUNDING STRATEGIES}

Polish biotech SMEs rely heavily on their own resources for R\&D, with nearly $60 \%$ of such expenditure of biotech firms in 2009 being self-funded (Nauka i Technika 2011 survey). Such an approach is summed up by Read-Gene's CEO, who says: "We invested our own funds [in the company]. I put in almost all of my savings, and the operating costs were not insubstantial" (Professor Jan Lubiński, CEO of Read-Gene, interview published on 27/05/2009 on biotechnologia.com.pl website).

Other major funding sources in 2009 included EU funds, with structural funds and other EU funds contributing about $34.0 \%$ of total expenditures of biotech companies (Nauka $i$ Technika, 2011). To quote the Raport (2007): “(...) the most important research in Poland is conducted based on EU money and grants from foreign universities" (Raport, 2007).

Among public SME biotechs, Mabion has received the largest amount of funds from the EU, with nearly 40 million PLN planned to be given from the Programme Innovative Economy between 2010 and 2014. Compared to Mabion's 2010 revenue of $3.1 \mathrm{mln}$ PLN, this is substantial. This is similarly true of Euroimplant for lab construction, and to a smaller extent, to Read-Gene.

Whilst EU funding is important, its impact should not be over-estimated. Importantly, EU funding is short-term compared to product development times within biotechnology. Moreover, such funding can also be unpredictable in timing and uncertain as the process of refunding investment from the EU is often delayed, one of the main reasons why Euroimplant 
reported a net loss in 2010. Finally, there is also the danger that EU funds will have to be repaid later if associated conditions are not met.

Launching an Initial Public Offering (IPO) on the Warsaw Stock Exchange is becoming an increasingly popular source of funding. This is often vital as each company that applies for EU money has to prove it can contribute at least $25 \%$ of the costs to a project. With regard to this, Read-Gene's CEO Professor Jan Lubiński says: "Money that comes from IPO and subsequent capital raises is necessary to launch some EU co-funded project" (Professor Jan Lubiński, CEO of Read-Gene, interview published on 04/092008 on www.inwestycjealternatywne.pl).

Sometimes using funding from an IPO may be the only strategy to access finance and remain independent of both big pharma corporations or venture capital. Such 'independent behaviour' (Type F) is nicely summed up by Professor Jan Lubiński, who explains the reasons why Read-Gene launched an IPO: "We decided in favour of an IPO because we were not treated well by the large capital providers. They wanted everything in return for nothing. They thought that we wouldn't manage to raise any capital without them. They were wrong. An «ordinary Kowalski» ${ }^{6}$ trusted us and it worked out" (Professor Jan Lubiński, CEO of Read-Gene, interview published on 27/05/2009 on biotechnologia.com.pl website).

The representative of one of the larger Polish private biotech companies summarises this as follows: "The company does not use venture capital - it's difficult to sell to someone your own, authored idea" (interview no. 4, 25/08/2010).

Moreover, Professor Jan Lubiński concludes that he: “(...) had a general feeling that venture capital funds intended to control the majority of shares but only in return for a small investment" (interview published on 04/09/2008 on www.inwestycjealternatywne.pl).

This desire for independence suggests a self-confidence and wish for autonomy by the owner/researcher concerned and so contradicts to some extent with Sztompka's (1996) comments regarding the lack of independent behaviour rooted in the communist heritage.

This independent behaviour fits in well with the model observed in the Polish biotech sector where some companies (Selvita, a private firm as at end of 2010 and Euroimplant) operate in an 'investor cum entrepreneur' mode (see Fig. 1). For instance, Selvita was founded and has been managed by two IT engineers who invested their money earned in one of the largest software development companies in Poland for a promising biotech project. It is quite common for companies not only to use own financial resources of entrepreneurs, but to use EU funds as widely as it is possible (in particular to build lab infrastructure). For all three quoted biotech SMEs EU funding (pledged for varying periods from 2009 onwards) substantially contributes to the companies' operations. EU funding therefore, whilst historically relatively insignificant, is becoming increasingly important to the development of quoted biotech SMEs in Poland.

${ }^{6}$ Kowalski is a common Polish surname similar to Smith in Anglo-Saxon countries. In making this comment, Jan Lubiński means that small individual investors had faith in the firm's IPO and so bought shares of the company. Importantly, the New Connect stock exchange on which Read-Gene floated its shares attracts mainly small investors. 
The other very common form of independence strategy, which is necessarily limited on an organisational scale, is to set up and run a single-person micro-firm, often by an academic (see Tab. 2). Such entrepreneurs treat their businesses as a source of extra income on top of their academic work and also: "profit from doing consultancy work" (interview no. 5, 10/04/2010).

The same entrepreneur says he has: “(...) about more than a dozen small contracts per year" (interview no. 5, 10/04/2010).

These micro-firms perform well - out of 21 SME Polish private biotech companies, 13 reported profits in 2009 in contrast to the losses more usually reported by publicly quoted biotech firms.

From our review of such funding strategies by Polish biotech entrepreneurs, we argue that these suggest a deep-seated desire for autonomy in the running of their businesses.

\section{Conclusions}

The key contribution of this paper is to have extended analysis of the Welter and Smallbone (2011) typology of entrepreneurial behaviour to the case of a knowledge-intensive industry, biotech, in contrast to the majority of their examples which concerned manufacturing and trade. Moreover, in our study we have contributed to the typology, the additional types of confrontation and independence. In our view, Poland does continue to represent a challenging environment at least for a knowledge-intensive industry such as biotech, because of its institutional challenges, which partly date back to its communist heritage. These include the poor linkages between science and industry and although newly established, PARP's rigidity and low understanding of biotech reminiscent of the communist era. We have argued that such institutional challenges provide a constraint on entrepreneurial behaviour.

The important question arises: to what extent the identified barriers are specific for the biotech industry, or do they apply for the whole Polish economy. When it comes to weak institutional framework it is a common feature many businesses must face up to in Poland. However, very low understanding of industry is more specific to a knowledge-intensive industry than a socialist legacy.

By discussing these institutional challenges, we have attempted to explain why the Polish biotech industry is not performing well relative to its potential.

With regard to the eight elements in the institutional structure of biotechnology distinguished by Bartholomew (1997), only a national tradition of scientific education is present. Other institutional aspects (e.g. the level and patterns of national funding of basic research and the degree of commercial orientation of R\&D institutions, in particular) are lacking. The highly limited role of government in supporting the sector, expensive patenting and the changing legal framework cause the performance of the Polish biotech sector to lag behind its potential. In the absence of a flourishing venture capital sector, EU and own funding make 
up most of the shortfall. However, we have argued that despite the institutional challenges facing the development of the biotech sector in Poland, we have uncovered evidence of independent behaviour and a deep-seated desire for autonomy in the running of business on the part of some Polish biotech entrepreneurs.

Further research based on anonymous semi-structured interviews with entrepreneurs could explore other behaviours in the Welter and Smallbone (2011) typology, such as networking and more difficult to uncover issues such as tax evasion. Importantly also, further research should explore in greater depth from an institutional perspective, the applicability or otherwise of the Bartholomew elements of the biotech industry framework such as linkages to foreign research institutions and labour mobility to the Polish case, concerns which were outside the remit of the current study. Findings from such studies would have important policy implications for the development of the Polish biotech industry.

\section{References}

Bajka o polskiej nauce. (2012). Retrieved April 25, 2012, from http://bioinfo.pl/about.html.

Bartholomew, S. (1997). National systems of biotechnology innovation: complex interdependence in the global system. Journal of International Business Studies, 28(2), 241-267.

Clarysse, D., Degroof, J.-J., Heirman, A. (2003). Growth paths of technology-based companies, in life sciences and information technology. European Commission, Directorate-General for Enterprises, Innovation Papers, 32.

Estrin, S., Mickiewicz, T. (2010). Entrepreneurship in Transition Economies: The Role of Institutions and Generational Change. Institute of the Study of Labour. Discussion Paper No. 4805.

Froud, J., Johal, S., Leaver, A., Williams, K. (2006). Financialization and strategy: narrative and numbers. London: Routledge, Taylor and Francis.

Haslam, C., Tsitsianis, N., Gleadle, P. (2011). UK bio-pharma: innovation, re-invention and capital at risk. Edinburgh: The Institute of Chartered Accountants of Scotland.

Kuzdraliński, A. (2012). "Polska bioinformatyka stosowana", interview with Leszek Rychlewski, the founder of BioInfoBank Institute. Retrieved April 25, 2012, from http://www.e-biotechnologia. pl/Artykuly/Bioinformatyka-stosowana/.

Malo, S., Norus, J. (2009). Growth dynamics of dedicated biotechnology firms in transition economies. Evidence from the Baltic countries and Poland. Entrepreneurship \& Regional Development, 21(5/6), 481-502.

Manolova, T., Eunni, R.V., Gyoshev, B. (2008). Institutional environments for entrepreneurship: Evidence from emerging economies in Eastern Europe. Entrepreneurship Theory and Practice, $32(1), 203-218$.

Moore, A. (2004). Accession without concession. European Molecular Biology Organization, Reports 5, 935-938.

Mroczkowski, T., Elms, H. (2009). Tracking progress: two approaches to biotechnology developmentcases from Central Europe. Journal of Commercial Biotechnology, 15(3), 227-235.

Nauka i Technika w Polsce w 2009 roku. (2011). Warszawa: Main Statistical Office, Statistical Office in Szczecin.

Niosi, J. (2011). Complexity and path dependence in biotechnology innovation systems. Industrial and Corporate Change, 20(6), 1795-1826.

North, D.C. (1990). Institutions, Institutional Change, and Economic Performance. Cambridge: Cambridge University Press. 
North, D.C. (1994). Economic Performance through Time. American Economic Review, 84(3), 359368.

Peng, M.W. (2000). Business Strategies in Transition Economies. Thousand Oaks, CA, and London: Sage.

Peng, M.W. (2003). Institutional transitions and strategic choices. Academy of Management Review, 28(2), 275-286.

Piasecki, B., Rogut, A. (1993). Self-regulation of SME sector development at a more advanced stage of transformation. The 20 th Annual Conference of E.A.R.I.E., Tel-Aviv, September 1993.

Raport na temat barier komercjalizacji wyników badań naukowych $w$ dziedzinie life science w Małopolsce. (2007). Kraków: Jagiellońskie Centrum Innowacji.

Rogut, A., Cieślak, M. (2009). A Portrait of Regional Technology Transfer Institutions. In: B. Piasecki, K. Kubiak (eds.), Partnership for Innovation. Łódź: Wydawnictwo SWSPiZ, 249-262.

Smallbone, D., Welter, F. (2006). Conceptualising Entrepreneurship in a Transition Context. International Journal of Entrepreneurship and Small Business, 3(2), 190-206.

Smallbone, D., Welter, F. (2009a). Entrepreneurial Behaviour in Transition Environments. In: M.-Á. Galindo, J. Guzman, D. Ribeiro (eds.), Entrepreneurship and Business in Regional Economics. New York: Springer, 211-228.

Smallbone, D., Welter, F. (2009b). Entrepreneurship and Small Business Development in Post-Socialist Economies. London: Routledge.

Smallbone, D., Welter, F. (2010). Entrepreneurship and the Role of Government in Post-Socialist Economies: Some Institutional Challenges. Historical Social Research - Historische Sozialforschung, 35(2), 320-333.

Smallbone, D., Welter, F., Voytovich, A., Egorov, I. (2010). Government and entrepreneurship in transition economies: the case of small firms in business services in Ukraine. The Service Industries Journal, 30(5), 655-670.

Suurna, M. (2011). The developments in the business models of biotechnology in the Central and Eastern European countries: the example of Estonia. Journal of Commercial Biotechnology, 17, 84-108.

Sztompka, P. (1996). Looking Back: The Year 1989 as a Cultural and Civilizational Break. Communist and Post-Communist Studies, 29(2), 115-129.

Van Beuzekom, B., Arundel, A. (2009). OECD Biotechnology Statistics. Paris: OECD.

Welter, F. (2011). Contextualizing Entrepreneurship - Conceptual Challenges and Ways Forward. Entrepreneurship: Theory and Practice, 35(1), 165-184.

Welter, F., Smallbone, D. (2011). Institutional Perspectives on Entrepreneurial Behaviour in Challenging Environments. Journal of Small Business Management, 49(1), 107-125.

Witek, R. (2008). Ochrona i komercjalizacja wyników badań uzyskiwanych we wspótczesnych naukach przyrodniczych. WTS Rzecznicy Patentowi, Witek, Śnieżko i Partnerzy. Retrieved April 25, 2012, from http://www.wtspatent.pl/files/pl6.pdf. 
Appendix. Comparative characteristics of the three Polish biotech SMEs quoted as at the end of 2010

\begin{tabular}{|c|c|c|c|}
\hline & Mabion & Read-Gene & Euroimplant \\
\hline Profile & $\begin{array}{l}\text { Oncology, development } \\
\text { of humanised monoclonal } \\
\text { antibodies (mAbs) } \\
\text { technology }\end{array}$ & $\begin{array}{l}\text { Methods of detection, } \\
\text { prevention and treatment } \\
\text { of the most common } \\
\text { types of malignant } \\
\text { tumours }\end{array}$ & $\begin{array}{l}\text { Tissue engineering } \\
\text { (epidermal grafts; } \\
\text { cosmetic petals under the } \\
\text { eyes). Composite collagen } \\
\text { products }\end{array}$ \\
\hline Employment & 14 & 6 & 18 \\
\hline $\begin{array}{l}\text { Year of } \\
\text { establishment }\end{array}$ & 2007 & 2005 & 2006 \\
\hline IPO date & 2010 & 2009 & 2008 \\
\hline $\begin{array}{l}\text { Market value } \\
\text { (mln PLN)* }\end{array}$ & 94.53 & 62.49 & 83.96 \\
\hline $\begin{array}{l}\text { IPO value (mln } \\
\text { PLN) }\end{array}$ & $\begin{array}{l}1.9 \text { in public offering, } \\
22.8 \text { in private offering } \\
\text { for shareholders before } \\
\text { IPO }\end{array}$ & 4.0 & 11.1 \\
\hline $\begin{array}{l}\text { Revenue (2010, } \\
\text { PLN) }\end{array}$ & $3,084,918$ & 363,643 & 721,423 \\
\hline $\begin{array}{l}\text { Net profit/ (loss) } \\
(2010, \text { PLN) }\end{array}$ & 471,450 & $(399,200)$ & $(2,370,309)$ \\
\hline Product/service & $\begin{array}{l}\text { Generics }+ \text { development } \\
\text { of own products }\end{array}$ & Services + R\&D & Mass products + R\&D \\
\hline $\begin{array}{l}\text { Ownership } \\
\text { pattern }\end{array}$ & $\begin{array}{l}6 \text { Polish pharma } \\
\text { companies (including one } \\
\text { VC) }\end{array}$ & $\begin{array}{l}\text { Researcher - Professor } \\
\text { Jan Lubiński }\end{array}$ & $\begin{array}{l}\text { One quasi-venture } \\
\text { capitalist }+ \text { researcher }+1 \\
\text { drug specialist }\end{array}$ \\
\hline $\begin{array}{l}\text { Main financial } \\
\text { sources }\end{array}$ & $\begin{array}{l}\text { R\&D in collaboration } \\
\text { with scientific institutions } \\
+ \text { creation of teams for } \\
\text { particular research goals. } \\
\text { Will buy/in-licence } \\
\text { different technology as } \\
\text { needed }\end{array}$ & $\begin{array}{l}\text { Own R\&D + Scientific } \\
\text { collaboration }+ \\
\text { subcontracting. } \\
\text { Offers clinical trials to } \\
\text { other companies }\end{array}$ & $\begin{array}{l}\text { Own R\&D financed } \\
\text { largely by EU funds }+ \\
\text { scientific collaboration }\end{array}$ \\
\hline
\end{tabular}

Source: own elaboration based on companies' annual reports, other periodical financial information (semi-annual, quarterly), listing documents and New Connect data

Grzegorz Micek, Ph.D., Jagiellonian University. Research interests: local impact of global companies in IT industry, biotechnology and business services; proximity economics; applications of knowledge flows and spillovers concepts to regional development theories.

Pauline Gleadle, Ph.D., University of East Anglia, London. Research interests: financialization, especially in the biotech and pharmaceutical industries in the UK and internationally and the management of innovation.

Piotr Dawidko, MSc, Jagiellonian University. Research interests: geography of innovation and high-technology industries, regional innovation systems, the role of global production networks in the restructuring of post-communist economies, knowledge flows and spatial clustering. 


\section{Adres/address:}

Grzegorz Micek, Piotr Dawidko

Jagiellonian University

Institute of Geography and Spatial Management

ul. Gronostajowa 7, 30-387 Kraków, Poland

e-mail: grzegorz.micek@uj.edu.pl

piotr.dawidko@uj.edu.pl

\section{Adres/address:}

Pauline Gleadle

University of East Anglia, London

Norwich Business School

Norwich, Norfolk, NR4 7TJ, UK

e-mail: pauline.gleadle@gmail.com 